Personalidade Acadêmica Homenageada:

Raymundo Juliano Feitosa (Universidade Federal do Rio Grande do Norte - UFRN)

\title{
O ABORTO NÃO PODE ESPERAR: AS DIFICULDADES DAS VÍTIMAS DE ESTUPRO PARA O ABORTO LEGAL
}

\section{ABORTION CANNOT EXPECT: THE DIFFICULTIES OF RAPE VICTIMS FOR LEGAL ABORTION}

\section{DJÉSSICA DOS SANTOS PROCÓPIO}

Graduanda em Direito, modalidade integral, pela Escola Superior Dom Helder Câmara. Belo Horizonte - MG. E-mail: djessica.procopio@gmail.com

\section{CAIO AUGUSTO SOUZA LARA}

Mestre e Doutor em Direito pela Faculdade de Direito da Universidade Federal de Minas Gerais - UFMG. Professor da Escola Superior Dom Helder Câmara. Pesquisador Associado ao Programa RECAJ-UFMG - Acesso à Justiça e Solução de Conflitos. Secretário de Comunicação do Conselho Nacional de Pesquisa e Pósgraduação em Direito - CONPEDI. Belo Horizonte - MG. E-mail: caiolarabh@yahoo.com.br.

\section{RESUMO}

O tema-problema da pesquisa que se pretende desenvolver são as dificuldades enfrentadas pelas vítimas de violência sexual para terem acesso ao aborto legal no Brasil. Mesmo que a temática do aborto seja tão debatida atualmente, o desconhecimento acerca da legislação ainda é uma realidade social, principalmente, no que se refere ao direito ao abortamento legal às vítimas de estupro. Esta ignorância é visível quando se fala sobre o limite do tempo de gestação (22 semanas); o boletim de ocorrência, o exame de Instituto Médico Legal e a autorização judicial (os quais não são necessários); a identificação judicial do agressor (o que não é preciso). 
Personalidade Acadêmica Homenageada:

Raymundo Juliano Feitosa (Universidade Federal do Rio Grande do Norte - UFRN)

Segundo Marielle Franco, a quinta vereadora mais votada do Rio de Janeiro e coordenadora da Comissão de Defesa dos Direitos Humanos e Cidadania da Assembleia Legislativa do Rio de Janeiro (Alerj), "ao nos debruçarmos sobre os dados da motivação com maior recorrência para a procura dos serviços de aborto legal, o estupro, fica ainda mais nítido a negação de direitos e as violências a que às mulheres estão submetidas pela falta de oferecimento deste serviço". Esta perspectiva foi abordada pela socióloga no projeto de lei foi o ํㅜ 16/2017 a fim de institucionalizar o programa de atenção humanizada ao aborto legal para a cidade do Rio de Janeiro. Outrossim, salienta-se que o direito ao aborto humanitário é imprescindível em situações de estupro e que a garantia deste direito é essencial para a preservação, ainda que parcial, da saúde mental e psicológica da vítima, uma vez que o processo, além de ser precedido por atendimento psicológico, garante que vítimas de um crime tão brutal devem ser acolhidas pelo Estado. O problema objeto da investigação científica proposta é: em quais aspectos há uma ineficiência estatal acerca da asseguração do direito das vítimas de estupro ao abortamento legal? A partir das reflexões preliminares sobre o tema, é possível afirmar inicialmente que, no Brasil contemporâneo, o direito ao aborto legal, não penalizado pelo Art. 128 do Decreto-Lei № 2.848 do Código Penal de 1940, às vítimas de violência sexual não é, efetivamente, garantido ao grupo em destaque. O desconhecimento das vítimas, dos profissionais de saúde e das próprias unidades policiais acerca de legislação brasileira e a falta de instituições pertencentes ao Sistema Único de Saúde (SUS) que realizam o procedimento são os principais aspectos que impedem a asseguração deste direito. Portanto, as mulheres e meninas, as quais sofreram violência sexual e não almejam ser mães, têm como maior empecilho a defasagem e a ineficácia estatal, a qual, por sua vez, faz com que estas recorram às clínicas clandestinas ou submetam-se a uma gravidez indesejada. O objetivo geral do trabalho é analisar como o acesso das vítimas de estupro ao direito ao abortamento legal é dificultado pelo próprio Estado e seus respectivos órgãos. A pesquisa que se propõe pertence à vertente metodológica jurídico-sociológica. No tocante ao tipo de investigação, foi escolhido, na classificação de Witker (1985) e Gustin (2010), o jurídico-projetivo. O raciocínio desenvolvido na pesquisa será predominantemente dialético. De acordo com a técnica de análise de 
Personalidade Acadêmica Homenageada:

Raymundo Juliano Feitosa (Universidade Federal do Rio Grande do Norte - UFRN)

conteúdo, afirma-se que trata-se de uma pesquisa teórica, o que será possível a partir da análise de conteúdo dos textos doutrinários, normas e demais dados colhidos na pesquisa. A partir do exposto, conclui-se que a ineficácia da ação estatal é o principal motivador da não observância do direito das vítimas de estupro ao aborto legal. Empecilhos graves ainda existem e devem ser enfrentados pelas mulheres violentadas para a plena efetivação do seu direito, pois a realidade do país quanto a este direito ainda é machista, patriarcal e conservadora.

PALAVRAS-CHAVE: Direito Humanos; Aborto Legal; Estupro; Ineficiência Estatal.

\section{REFERÊNCIAS}

BELO, Warley Rodrigues. Aborto. Belo Horizonte: Del Rey, 1999.

BRASIL. Código Penal de 1940. Disponível em: http://www.planalto.gov.br/ccivil_03/_ato2011-2014/2013/lei/l12845.htm. Acesso em: 08 maio 2019.

Lei $\mathrm{n}^{\circ} \mathbf{1 2 . 8 4 5}$, de 1ํ $^{\circ}$ de agosto de 2013. Dispõe sobre 0 atendimento obrigatório e integral de pessoas em situação de violência sexual. Brasil: Casa Civil, [2013]. Disponível em: http://www.planalto.gov.br/ccivil_03/_ato20112014/2013/lei/l12845.htm. Acesso em: 21 maio 2019.

FONSECA, Jamile Guerra. Aborto legal no Brasil: avanços e retrocessos. 1ª . ed. Curitiba: Appris, 2018.

GUSTIN, Miracy Barbosa de Sousa; DIAS, Maria Tereza Fonseca. (Re)pensando a pesquisa jurídica: teoria e prática. 3ª . ed. Belo Horizonte: Del Rey, 2010.

GICO JÚNIOR, Ivo Teixeira. Pregnancy interruption under medical recommendation: the judicial activism of Brazilian Federal Supreme Court and Ronald Dworkin's liberal approach over fetal anencephaly cases. Revista Jurídica - UNICURITIBA, Curitiba, v.03, n.52, p.1-21, 2018. Disponível em: http://revista.unicuritiba.edu.br/index.php/RevJur/article/view/3044/371371579. Acesso em: 21 maio 2019.

LIMA, Beá. Oito semanas e 500 quilômetros, a distância percorrida entre um estupro e o atendimento médico correto. Portal El País Brasil. 18 nov. 2018. Disponível em: https://brasil.elpais.com/brasil/2018/11/07/politica/1541614854_118467.html. Acesso em: 21 maio 2019. 
Personalidade Acadêmica Homenageada:

Raymundo Juliano Feitosa (Universidade Federal do Rio Grande do Norte - UFRN)

RIO DE JANEIRO. Projeto de Lei no 16, de 15 de fevereiro de 2017. Institui o programa de atenção humanizada ao aborto legal e juridicamente autorizado no âmbito do município do Rio de Janeiro. Rio de Janeiro: Câmara dos Vereadores, [2017]. 07c006bfd36/2a88c90e900fa52d832580c800544af5?OpenDocument. Acesso em: 4 maio 2019.

SOUZA, Marcelle. Estado brasileiro não garante acesso ao aborto para vítimas de estupro. Portal Galileu. 08 dez. 2017. Disponível em: https://revistagalileu.globo.com/Ciencia/Saude/noticia/2017/12/estado-brasileiro-naogarante-acesso-ao-aborto-para-vitimas-de-estupro.html. Acesso em: 21 maio 2019.

WITKER, Jorge. Como elaborar una tesis en derecho: pautas metodológicas y técnicas para el estudiante o investigador del derecho. Madrid: Civitas, 1985. 